\title{
Robotbaby is goede test voor vaardigheden van risicoouders \\ rar
}

\author{
Jeugdzorginstelling Rading \\ zet een robotbaby in bij \\ ouders van uithuisgeplaatste \\ kinderen, de 'RealCare Baby'. \\ Door vijf dagen voor deze \\ robotbaby te zorgen, kun- \\ nen ouders bewijzen dat ze \\ de zorg voor hun echte kind \\ aankunnen. Werkt dat?
}

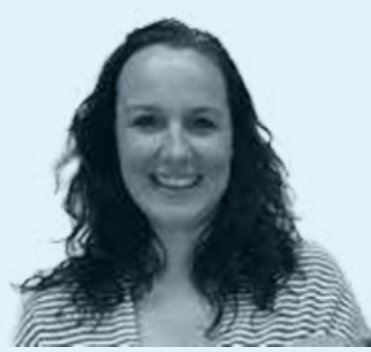

Veronique Groen

frontofficemedewerker en medewerker RealCare Baby bij Rading

'Wij zijn de eerste jeugdzorginstelling in $\mathrm{Ne}$ derland die de RealCare Baby inzet bij ouders van wie het kind direct of vlak na de geboorte uit huis is geplaatst. Deze robotbaby maakt onderdeel uit van een groter traject waarin we onderzoeken of ouders voldoende capaciteiten hebben om voor hun kind te zorgen. De ouders verzorgen de RealCare Baby vijf dagen. Ze krijgen allebei een armbandje om waarmee geregistreerd wordt hoe ze met de baby omgaan. Ouders zijn heel gemotiveerd om te laten zien dat ze het goed doen. De baby is levensecht. Hij ademt, kirt en hoest. Geef je hem te weinig eten of pak je hem niet goed vast, dan zet hij het op een krijsen. Wellicht dat ouders in die vijf dagen sociaal wenselijk gedrag vertonen en extra hun best doen om te laten zien dat ze het kunnen. Maar dat is het risico bij alle interventies die wij inzetten. Met de robotbaby kunnen we ouders ook beter voorbereiden op het zorgen voor hun kind. Via de RealCare Baby kunnen ze bijvoorbeeld leren dat de baby allerlei soorten huiltjes heeft, waar ze op verschillende manieren op moeten reageren. Wij hebben de RealCare Baby nu een paar keer ingezet en de ervaringen zijn goed. Eén keer bleek bijvoorbeeld dat ouders onvoldoende voeding hadden gegeven, wat ook een van de aanleidingen was voor de uithuisplaatsing van hun kind.'

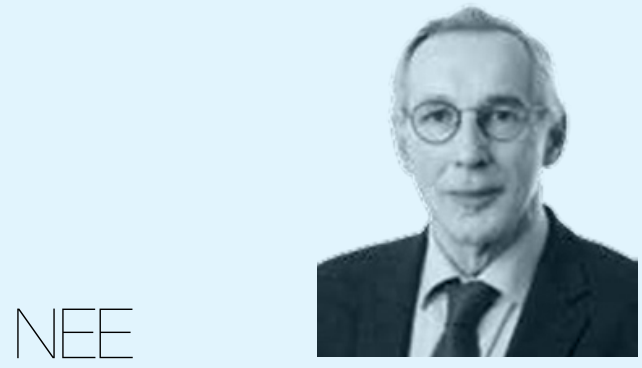

Paul Vlaardingerbroek hoogleraar familie- en jeugdrecht

'De robotbaby is een prima hulpmiddel om te beoordelen of ouders in staat zijn om de basiszorg te leveren. Het risico is echter dat de jeugdzorginstelling te optimistische conclusies verbindt aan de positieve resultaten. Ouders weten dat ze getest worden en zullen extra voorzichtig zijn met zo'n robotbaby. Ze gaan er wellicht minder ruw mee om omdat ze weten dat dat wordt geregistreerd. Mijn zorg is dat de jeugdzorginstelling dan denkt dat de baby wel terug kan, terwijl het kind toch nog risico loopt. Een echt kind is toch altijd anders dan een robotbaby, al is die nog zo goed nagemaakt. Wordt het echte kind een keer door elkaar geschud en je bent er als instelling niet bij, dan ben je mogelijk te laat. Bovendien wordt via de robotbaby niet getest of de ouders het kind voldoende emotionele aandacht geven. Daarom mag de robotbaby alleen een hulpmiddel zijn en moet de jeugdzorginstelling heel goede begeleiding en nazorg bieden als het kind daadwerkelijk wordt teruggeplaatst. De vraag is echter of een instelling er werkelijk bovenop kan zitten en snel kan ingrijpen als er een risico dreigt. Hebben ze echt de tijd om regelmatig bij de ouders binnen te lopen om te kijken of de luiers goed verschoond worden en het kind op tijd wordt gevoed? Er is geen instelling die 24-uurs zorg kan leveren. Bovendien: als je zo bang bent dat er iets mis gaat dat je er continu bewaking op moet zetten, dan zijn ouders er niet klaar of niet geschikt voor - ook al gun je het ze nog zo graag.' 